\title{
KEMITRAAN KONSERVASI DAN MASA DEPAN HUTAN PAPUA
}

\author{
Didin Hartoyo \\ Universitas Pertahanan \\ didinhartoyo@gmail.com \\ Erti Fadhilah Putri \\ Universitas Pertahanan \\ ertisafira@gmail.com \\ Kukuh Setyo Pambudi \\ Universitas Pertahanan \\ kukuhpambudi@ymail.com
}

\begin{abstract}
Abstrak
Persoalan tata kelola hutan merupakan salah satu permasalahan yang kerap membawa serta masyarakat kedalam konflik tenurial. Dalam mengatasi persoalan tenurial yang begitu besar di Indonesia, skema kemitraan koservasi coba untuk disusun oleh Kementrian KLHK. Tulisan ini bertujuan untuk memberikan satu evaluasi kritis terkait implementasi kebijakan kemitraan konservasi di Papua dan bagaimana seharusnya kebijakan ini dijalankan. Data dikumpulkan dengan mengunakan studi dokumen atau literature riview. Diharapkan tulisan ini dapat memberikan sebuah sarana evaluatif dalam mempercepat proses penyelesaian konflik tenurial dengan mengedepankan konsep kemitraan konservasi. Selanjutnya, diharapkan juga agar Papua menjadi satu basis implementasi kemitraan konservasi utamanya dalam menjaga masa depan hutan Papua. penguatan yang diharapkan adalah dengan menguatkan peran lembaga adat dan menjadikan konsep kemitraan konsevasi dengan menjadikan hutan sebagai salah satu tujuan wisata.
\end{abstract}

Kata kunci: kemitraan konservasi, hutan papua, konflik tenurial 


\section{PENDAHULUAN}

Masalah Pembalakan liar masih menjadi permasalahan di Indonesia. Saat ini Indonesia dihadapkan dengan laju deforestasi yang tertinggi di dunia. Menurut data World Resources Institute (WRI) Indonesia masuk dalam daftar 10 negara yang laju deforestasi tertinggi pada 2018 (Kusnandar, 2019). Dalam Laporan Kementerian Lingkungan Hidup dan Kehutanan (KLHK) tercatat bahwa laju deforestasi Indonesia pada 2018-2019 mencapai 465,5 ribu hektar (KLHK, 2020). Meskipun demikian angka tersebut merupakan angka yang relatif rendah dibanding tahun-tahun sebelumnya. Direktur Jenderal Planologi Kehutanan Dan Tata Lingkungan mengkonfrimasi ada sekitar 3,1 hektar lahan yang telah di reforestasi dari 465,5 yang mengalami deforestasi (KLHK, 2020). Adapun provinsi yang memiliki angka deforestasi yang tinggi di Indonesia pada periode 2017-2018 yakni Provinsi Papua, Kalimantan Timur, Kalimantan Barat, Riau dan Sulawesi Tenggara.

Provinsi Papua merupakan provinsi dengan angka deforestasi bruto tertinggi yaitu sebesar 84,6 ribu ha $(17,1 \%)$, posisi kedua ditempati Kalimantan Timur yakni sebesar 54,8 ribu ha (11,1\%). Pada deforestasi netto juga Papua menempati posisi pertama yakni sebesar 78,8 ribu ha (17,9\%) (Damarraya, Ratnasar, \& Rhama, 2019). Hal ini tentunya menjadi ancaman yang nyata bagi masyarakat Papua dimana tingkat degradasi alam semakin meningkat. Koordinator Desk Politik Wahana Lingkungan Hidup (Walhi) Khalisah Khalid menyebutkan bahwa saat ini Papua sedang menghadapi ancaman deforestasi terencana (Nainggolan, 2019). Sebagian hutan adat masyarakat Papua sedang dalam proses beralih fungsi menjadi sarana Infrastruktur. Dinas kehutanan Papua juga mengkonfirmasi bahwa penebangan ilegal di Papua kian meningkat intensitasnya. Penerbangan liar yang terjadi banyak menyasar pohon yang berada di kawasan konservasi dan hutan lindung.

Permasalahan pembalakan liar ini juga terjadi akibat tidak adanya kejelasan pengelolaan hutan adat masyarakat Papua. Banyaknya pengusaha yang memiliki izin yang manipulatif dengan mengatasnamakan pejabat seperempat menjadi perdebatan dengan masyarakat pemilik ulayat. Perda hutan adat belum ada padahal sangat penting untuk mengatur batas-batas wilayah adat. Kondisi inilah yang menjadi alasan KLHK belum mengeluarkan norma, standar, kriteria, dan prosedur (NSPK) untuk hak pengelolaan hutan adat. (Elisabeth, 2019).

Penerbangan liar yang terjadi di papua sebagian besar terjadi di Kabupaten Sorong, Manokwari, Fak Fak, Nabire dan Serui. Kayu gelondongan tersebut dikirim secara ilegal ke pelabuhan China di Zhangjiagang dan kemudian diangkut ke pabrik-pabrik di selatan Shanghai di mana kayu tersebut dibuat menjadi lantai kayu. Lebih dari 500 pabrik lantai telah didirikan di kota Nanxun hanya dalam 5 tahun. Pabrikpabrik ini memproses setidaknya satu kayu bulat merbau menjadi lantai. Setengah dari lantai kayu keras untuk ekspor. Keuntungan financial yang di dapat dari penebangan kayu Ilegal sebagian besar dinikmati oleh pengusaha-pengusaha asing dan lokal namun hanya sedikit yang didapatkan oleh masyarakat Papua. menurut Environmental Investigation Agency (EIA) Masyarakat Papua hanya menerima US \$ 11 untuk kayu yang dibutuhkan untuk membuat lantai seluas satu meter persegi. Sementara pengusaha asing mendapatkan keuntungan berkisar $250 \$$ per meter persegi (Earth, 2005). 
Melihat permasalahan pembalakan liar semakin marak dan cenderung merugikan masyarakat Papua yang tinggal dan menghuni Hutan. Sebagai pemilik hak ulayat, masyarakat Papua bergerak untuk mempertahankan tanah mereka sendiri, hal ini terjadi karena pemerintah dianggap belum dapat melindungi hutan sebagai sumber kehidupan masyarakat setempat. Koalisi masyarakat sipil menuntut agar pemerintah, dalam hal ini Kementerian Lingkungan Hidup dan Kehutanan, mengusut tuntas pelaku pembalakan liar di hutan Papua (TeropongNews, 2020).

Permasalahan yang mendasari adanya protes keras oleh masyarakat adat Papua adalah adanya IUPHHK-MHA atau Izin Usaha Pemanfaatan Hasil Hutan KayuMasyarakat Hukum Adat. Hal inilah yang menyebabkan tarik-menarik kepentingan antara berbagai stakeholder dalam pengelolaan hutan. Adanya perbedaan kepentingan antara pemerintah pusat dan pemerintah daerah juga membuat terjadi ketidakjelasan dalam mengimplementasikan peraturan perundang-undangan terkait hutan dan hukum adat. Peraturan-peraturan yang telah dibuat dianggap belum sinkron yakni antara peraturan sektoral kehutanan yang diterbitkan oleh pemerintah pusat dan Undang-Undang Otonomi Khusus Papua (UU Otsus Papua) dan peraturan pelaksananya serta dengan kehadiran peraturan pemerintahan daerah (Muhajir, 2018).

Selain IUPHHK-MHA yang banyak menimbulkan gesekan antara masyarakat dan perusahaan. IUPHHK-HTI atau Izin Usaha Pengelolaan Hasil Hutan Kayu Hutan Tanaman Industri juga menimbulkan gesekan. Hal ini terjadi pada tahun 2007 dimana masyarakat meminta ganti rugi lahan seluas 2.800 hektar kepada perusahaan $\mathrm{T}$.
Medco Papua Industri Lestari di Merauke. Perampasan tanah adat tersebut akan ditanami menjadi perkebunan sawit. Selain konflik antar perusahaan dan masyarakat konflik juga terjadi antara pemerintah dan masyarakat ada di mana pemerintah meminta pembebasan lahan untuk infrastruktur. Pemerintah cenderung menggunakan cara pemaksaan dengan pendekatan militer dan intimidasi yang dapat menjadi pemicu konflik lahan (Muhajir, 2018)

Dalam tulisan ini akan membahas bagaimana menyelesaikan konflik tenurial yang ada di sebagian wilayah Papua dengan pendekatan kemitraan nantinya pendekatan ini akan menjadi solusi terhadap permasalahan lahan yang saat ini terjadi di Papua. Selain itu kejelasan hukum dan integrasi antar lembaga dalam menyelesaikan konflik juga diperlukan.

\section{TINJAUAN TEORI}

\section{Konsep Kemitraan Konservasi}

Kemitraan dapat didefinisikan sebagai bentuk kerjasama antar stakeholder yang saling menguntukan dalam mencapai tujuan bersama. Nilai-nilai yang ada pada konsep kemitraan ini adalah konsep saling percaya, saling menguntungkan dan gotong royong. Konsep kemitraan menurut Christ (2008), adalah sebuah konsep kerjasama yang memfokuskan pada aspek "caring": yang saling memberikan empati dan perhatian pada mitra sehingga menghasilkan kebermanfaat dan keuntungan (Surono, 2008). Kemitraan atau pelibatan masyarakat dalam pengelolaan hutan bukanlah hal yang baru bagi pemerintah indonesia. Pelibatan masyarakat dalam pengelolaan hutan sejak lahirnya UU No. 5/1990 hingga saat ini (Prayitno, 2020). 


\begin{abstract}
Kemitraan konservasi bertujuan selain melindungi alam juga mengendepankan pengembagkan dan pemberdayaan masyarakat sekitar kawasan hutan. Kemitraan konservasi sendiri dalam Peraturan Direktur Jenderal Konservasi Sumber Daya Alam dan Ekosistem Nomor P.6/KSDAE/SET/Kum.1/6/2018 tentang Petunjuk Teknis Kemitraan Konservasi Pada Kawasan Suaka Alam dan Kawasan Pelestarian Alam, dimaknai sebagai kerja sama antara kepala unit pengelola kawasan atau pemegang izin pada kawasan konservasi dengan masyarakat setempat berdasarkan prinsip saling menghargai, saling percaya, dan saling menguntungkan (Prayitno, 2020).
\end{abstract}

Kemitraan konservasi terbagi menjadi 2 jenis kegiatan yaitu kemitraan konservasi dalam rangka pemberdayaan masyarakat setempat dan kemitraan konservasi dalam rangka pemulihan ekosistem. Dimana dalam kemitraan, masyarakat akan diarahkan pada blok pemanfaatan dengan mempertimbangkan aksesibilitas, tingkat kesejahteraan masyarakat, dan potensi sumber daya hutan non-kayu/perairan yang tidak dilindungi.kemudian terdapat pula kemitraan konservasi pemulihan ekosistem dimana tujuan dari kemitraan adalah melakukan kerjasama dalam pemulihan kembali hutan (Mutiono, 2020).

\section{TEORI KEBUTUHAN DASAR MANUSIA}

Konflik dapat disebabkan karena tidak terpenuhinya kebutuhan dasar manusia hal ini selaras dengan pendapat John Burton dalam bukunya yang berjudul Conflict: Resolution and Prevention (1990) menyatakan bahwa konflik bersumber dari basic human needs atau kebutuhan dasar manusia. Setiap keinginan merupakan perwujudan dari pemenuhan kebutuhan dasar. Dalam literatur lain disebutkan bahwa manusia memiliki tingkatan pemenuhan kebutuhan dasar yang harus dipenuhi. Ahli psikologi Maslow membagi kebutuhan dasar tersebut kedalam beberapa kategori dalam sebuah piramida.

1. Physiological (Fisiologi). Physiological needs atau kebutuhan fisiologi seringkali disebut sebagai basic needs atau kebutuhan dasar. Kebutuhan fisiologi antara lain meliputi sandang, pangan, papan dan kebutuhan biologis lainnya.

2. Safety (Rasa Aman). Yang dimaksud dengan kebutuhan rasa aman antara lain meliputi keamanan (security) dan proteksi (perlindungan) dari gangguan.

3. Social (Sosial) atau Belongingness Needs. Kebutuhan sosial antara lain meliputi cinta kasih (affection), rasa memiliki, penerimaan sosial (acceptance) dan perkawanan (friendship).।

4. Esteem (Penghargaan). Kebutuhan akan penghargaan terdiri dari dua jenis, yaitu internal esteem (penghargaan internal) dan external esteem (penghargaan eksternal).

5. Self-actualization (Aktualisasi Diri). Kebutuhan aktualisasi diri merupakan dorongan pada diri seseorang untuk menjadi orang yang capable (memiliki kemampuan handal),

Dalam teori kebutuhan dasar ini dijelaskan bahwa kebutuhan yang lebih rendah dalam hierarki harus dipenuhi sebelum individu dapat memenuhi kebutuhan yang lebih tinggi. Dari hierarki bawah ke atas, kebutuhannya adalah: fisiologis, 
keamanan, cinta dan kepemilikan, harga diri, dan aktualisasi diri.

\section{Adat Papua}

Masyarakat adat Papua sangat tergantung dengan Hutan. Selain sebagai tempat tinggal hutan juga digunakan sebagai sumber daya memenuhi kebutuhan dasar. Selain itu masyarakat Papua juga sangat menghormati hutan dimana juga merupakan tempat yang sakral. Salah satu contoh suku di Papua yang sangat tergantung dengan hutan adalah suku Korowai. Suku Korowai memiliki adat dan tradisi untuk tinggal menetap di hutan di atas pohon yang tinggi. Suku ini memiliki kehidupan yang seimbang, dimana mereka begitu menjaga hubungan antara sesama manusia dan alam (Asriyati, 2019).

\section{KEMITRAAN KONSERVASI DI INDONESIA}

Kemitraan atau pelibatan masyarakat dalam pengelolaan hutan termasuk kawasan konservasi, sebenarnya sudah dilakukan pemerintah sejak lama. Jika merunut dari berbagai kebijakan pemerintah, kemitraan atau pelibatan masyarakat dalam pengelolaan hutan dimulai sejak lahirnya UU No. 5/1990 kemudian terdapat pembaharuan peraturan hingga yang terbaru adalah Perdirjen KSDAE No. 6 Tahun 2018 (KLHK, 2015).

Salah satu penerapan atau pengimplementasian dari Perdirjen KSDAE No. 6 Tahun 2018. Kemitraan konservasi taman nasional kutai. Taman Nasional Kutai merupakan kawasan memiliki persoalan kompleks multistakeholder dimana bukan saja permasalahan konflik tenurial yang menjadi permasalahan namun juga konflik kepentingan dengan motif ekonomi juga menjadi permasalahan di kawasan ini. kawas Taman Nasional kutai terletak di antara kota Bontang dan Sangatta yang sedang mengalami pengembangan dan pembangunan. Kawasan TNK ini juga dikelilingi oleh perusahaan tambang dan industri. Kondisi Taman Nasional Kutai sendiri sudah memprihatinkan dengan berbagai macam kerusakan alam yang terjadi. Untuk mengatasi permasalahan kompleks tersebut pengelolaan yang berbasis kemitraan menjadi solusi. Mitra Taman Nasional Kutai merupakan salah satu contoh konsep kerjasama kemitraan yang ada di Indonesia yang kemungkinan dapat diaplikasikan di wilayah kawasan pelestarian alam dan kawasan suaka alam lainnya (KLHK, 2020).

Dalam pengelolaan kawasan terdapat prinsip-prinsip khusus yang disepakati oleh stakeholder, misalnya saja prinsip pengelolaan zona khusus TNK yang berkaitan dengan keberadaan masyarakat. Adapun prinsip pengelolaan yang ada meliputi yang dikembangkan oleh Balai TN Kutai (2010)sebagai berikut:1. Status kawasan tetap dipertahankan sebagai kawasan TN Kutai 2. Letak zona khusus berada pada wilayah yang telah disepakati sebelumnya untuk ditata batas pengamanan 3. Pemanfaatan lahan diberikan kepada penduduk yang telah tinggal, memiliki lahan dan hidupnya tergantung pada lahan tersebut sebelum TN Kutai ditunjuk 4. Tidak mengakomodir kepemilikan lahan oleh masyarakat yang tinggal di dalam zona khusus 5. Pengelolaan akan dilaksanakan oleh lembaga khusus yang bertanggung jawab kepada Balai TN Kutai 6. Zona khusus akan terbagi menjadi areal pemukiman, areal pemanfaatan dan areal lindung 7 . Pengelolaan di dalam zona khusus akan diarahkan menjamin kehidupan yang ramah lingkungan dan berupaya untuk mempersiapkan generasi mendatang untuk mendapatkan kehidupan yang layak di luar zona khusus (KLHK, 2015). 
Dalam proses pengimplementasian kemitraan pada TN kutai terdapat beberapa faktor yang mempengaruhi keberhasilan program. Adapun salah satu faktor yang menjadi faktor pendukung keberhasilan adalah Zona pemanfaatan di TN Kutai yang dimanfaatkan sebagai tempat wisata alam atau ekowisata (Sawitri dan Karlina, 2013) yang tentunya hal ini dapat mendorong kesinambungan kemitraan dengan membawa kesejahteraan bagi masyarakat sekitar. Berikut ini adalah objek wisata yang ada di Zona Manfaat.

\section{a. Prevab}

Merupakan Objek wisata yang daya tarik utama nya adalah keberadaan satwa liar orangutan dan penyusuran tracking di hutan Dipterocarpaceae. Selain dapat melihat keberadaan satwa endemic Kalimantan pengunjung dapat pula menanam pohon lokal yang ada di kalimantan salah satu yang paling populer adalah Ulin, Sangkuang, Kelengkeng hutan dan lain sebagainya

b. Teluk Kaba

Obyek wisata lainnya di TN kutai adalah Wisata Teluk Baba dimana masyarakat Desa Sangkima Lama, Kecamatan Sangatta Selatan, Kabupaten Kutai Timur mendirikan Koperasi Jasa Pariwisata Teluk Kaba beranggotakan 10 orang yang terdiri dari nelayan dengan pekerjaan utama sebagai petani rumput laut dan mengambil ikan disamping sebagai petani dengan lahan garapan sekitar 4-5 ha. Kegiatan yang disodorkan masyarakat adalah pariwisata pantai dan naik perahu, kuliner ikan laut, hasil olahan rumput laut.

c. Saleba
Obyek wisata lainnya adalah Saleba yakni sebuah areal perkemahan yangmdikembangkan oleh TN Kutai bersama dengan stakeholder maupun masyarakat yang tergabung dalam kemitraan Bontang Mangrove. Kawasan yang sebelumnya dikelola masyarakat, kemudian dikembalikan ke fungsinya melalui aksi penanaman dalam rangka mewujudkan penanaman 1 milyar pohon, jenis tanaman perkayuan dan buah-buahan yang dibudidayakan diantaranya meranti, kapur, hopea, puspa, Dryobalanops sp., Shorea balangeran, gaharu, nyatoh serta durian rambutan dan mangga

Kunci keberhasilan lainnya adalah adanya inovasi kemitraan dalam rangka pemulihan ekosistem di TN Kutai adalah dengan menggunakan pendekatan komunikasi intensif menjadi faktor keberhasilan implementasi lapangan. Kondisi terpenting yang mutlak diperlukan adalah adanya pengakuan eksistensi kawasan oleh masyarakat sebagai mitra pengelolaan kawasan. Hal ini mendukung pemantapan kawasan yang mendorong terwujudnya kelestarian berkelanjutan. Inovasi kemitraan juga telah diterapkan pada kawasan-kawasan konservasi lainnya seperti TN Leuser, TN Rawa Aopa, SM Paliyan, dan sebagainya (KLHK, 2015).

\section{KEMITRAAN KONSERVASI DI PAPUA}

\section{Teluk Cendrawasih}

Kawasan Taman Nasional teluk Cendrawasih merupakan salah satu kawasan taman nasional perairan yang ada di Indonesia. Kawasan TN Teluk Cendrawasih memiliki zona inti dengan potensi dan keterwakilan ekosistem penting berupa ekosistem mangrove, habitat berbagai jenis 
burung yang dilindungi, ekosistem terumbu karang, vegetasi pantai, pantai peneluran penyu, ekosistem berbagai jenis biota laut yang dilindungi seperti kimia dan penyu, tempat kegiatan religi dan budaya masih dilestarikan oleh masyarakat (Balai Besar TN Teluk Cendrawasih dan World Wide Fund (WWF)-Indonesia, 2009).

Taman Nasional Teluk Cendrawasih (TNTC) merupakan perwakilan ekosistem terumbu karang, pantai, mangrove dan hutan tropika dataran pulau di Papua. TNTC memiliki tingkat keanekaragaman hayati yang tinggi, termasuk terumbu karang. Keberadaan ekosistem terumbu karang yang ada di kawasan TNTC belakangan ini telah mengalami kemunduran fungsi baik secara ekologis maupun fisik. Kemunduran ini diakibatkan oleh aktivitas manusia dalam memanfaatkan sumberdaya di terumbu karang yang bersifat merusak, seperti penangkapan dengan cara yang tidak ramah lingkungan (bom dan racun), dan penangkapan biota yang berlebihan. Upaya yang dilakukan pemerintah ialah dengan melakukan sistem pengelolaan dan badan pengelolaan Taman Nasional yang merupakan kawasan pelestarian alam yang mempunyai ekosistem asli, dikelola dengan sistem zonasi yang dimanfaatkan secara bersama (KLHK, 2015).

Dalam mengatasi permasalahan yang dihadapi TN Teluk Cendrawasih diperlukan kemitraan kolaboratif antara stakeholder yang terkait. Kemitraan konservasi ini nantinya dapat mengurangi dan juga mengatasi permasalahan kerusakan alam yang terjadi. Selain itu kemitraan konservasi dapat meberdayaan dan mengemangkan masyarakat sekitar kawasan.

Dalam mengimplementasikan program kemitraan yakni, WWF dan Bali TN Teluk Cenderawasih yakni dengan melalui peningkatan kontribusi Penerimaan Negara Bukan Pajak (PNBP) dari pengusaha jasa lingkungan (200 Milyar rupiah) yang dimaksudkan dapat memberikan kemudahan dalam pembangunan infrastruktur di TNTC. WWF Memfasilitasi penyusunan rencana pengelolaan taman nasional termasuk mendukung kegiatan survey dan mendorong adanya sumber pendapatan bagi masyarakat lokal secara berkelanjutan (melalui perikanan dan pariwisata) serta membangun sistem pembiayaan berkelanjutan, bersama dengan Papua Barat Guna menunjang peningkatan kontribusi PNBP dari pengusahaan jasa lingkungan maka Balai Besar Taman Nasional Teluk Cendrawasih pada tahun 2015 sesuai dengan perjanjian kinerja telah menargetkan kunjungan wisata sebanyak 1482 orang dan sesuai data statistik 2015, maka pengunjung yang masuk ke kawasan TNTC selama tahun 2015 sebesar 5722 orang. Jika dibandingkan dengan 5 tahun terakhir maka telah terjadi peningkatan pengunjung sekitar $700 \%$ di tahun 2015 (Purmadewi, 2018).

Sebagai taman nasional dengan perairan terluas di Indonesia TNTC telah dihadapkan dengan berbagai permasalahan dalam pengelolaanya. Permasalahan utama yang dihadapi adalah terbatasnya kapasitas kelembagaan. Kelembagaan belum dalam mengembangkan konsep pariwisata yang terpadu dalam pemberdayaan masyarakat setempat. Saat ini memang kawasan TNTC merupakan kawasan favorit wisatawan lokal dan asing namun dalam segi fasilitas TNTC belum dapat mengintegrasikan konsep pariwisata yang terpadu dan cenderung memanfaatkan teknologi dan jejaring komunikasi secara optimal. Selain permasalahan internal TNTC juga di hadapkan dengan sikap resisten masyarakat terhadap keberadaan kawasan TNTC (KLHK, 2015). Tentang kondisi sosial politik 
nasional dan regional serta pemanfaatan sumber daya alam dengan cara-cara yang tidak ramah lingkungan juga merupakan tantangan tersendiri dalam pengelolaan kawasan TNTC (Purmadewi, 2018).

Aspek pariwisata menjadi poros pengelolaan kawasan TNTC yang tentunya melibatkan peran masyarakat dan para pihak terkait dalam (Purmadewi, 2018) pellaksanaannya. Aktivitas pariwisata di kawasan TNTC dapat dikatakan mengalami peningkatan yang signifikan sejak tahun 2012. Pada tahun 2012, jumlah pengunjung meningkat lebih dari dua kali lipat dari tahun sebelumnya dan pada tahun 2015 jumlah pengunjung mencapai angka 5.722 orang (Purmadewi, 2018).

Peningkatan kunjungan ini berdampak positif pada peningkatan Pendapatan Negara Bukan Pajak (PNBP). Salah satu hal yang menjadi daya tarik wisatawan baik domestik maupun mancanegara untuk mengunjungi TNTC adalah keberadaan Hiu Paus (Rhincodon typus) yang oleh masyarakat lokal disebut sebagai Gurano Bintang. Jenis ikan ini telah mendapatkan status perlindungan penuh di Indonesia melalui Keputusan Menteri Kelautan dan Perikanan Republik Indonesia Nomor 18/Kepmen-Kp/2013 tertanggal 20 Mei 2012 tentang Penetapan Status Perlindungan Penuh Ikan Hiu Paus (R. typus). Status perlindungan penuh ini berkaitan dengan seluruh siklus hidup dan/atau bagian-bagian tubuh hiu paus.

Peningkatan kunjungan ini berdampak positif pada peningkatan Pendapatan Negara Bukan Pajak (PNBP). Salah satu hal yang menjadi daya tarik wisatawan baik domestik maupun mancanegara untuk mengunjungi TNTC adalah keberadaan Hiu Paus (Rhincodon typus) yang oleh masyarakat lokal disebut sebagai Gurano Bintang. Jenis ikan ini telah mendapatkan status perlindungan penuh di Indonesia melalui Keputusan Menteri Kelautan dan Perikanan Republik Indonesia Nomor 18/Kepmen-Kp/2013 tertanggal 20 Mei 2012 tentang Penetapan Status Perlindungan Penuh Ikan Hiu Paus (R. typus). Status perlindungan penuh ini berkaitan dengan seluruh siklus hidup dan/atau bagian-bagian tubuh hiu paus (KLHK, 2015).

Berdasarkan International Union for Conservation of Nature (IUCN), jenis ikan ini berubah status menjadi endangered dan dataset IUCN menunjukkan penurunan populasi sebesar $63 \%$ selama 75 tahun (3 generasi) di perairan Indo-Pasifik. Tingginya minat wisatawan untuk berinteraksi dengan satwa perairan ini secara langsung maupun tidak langsung akan berdampak pada kondisi ekosistem dan individu hiu paus itu sendiri. Oleh karena itu, pengelolaan aktivitas pariwisata hiu paus di TNTC perlu ditingkatkan guna menjamin terwujudnya keseimbangan antara aktivitas pemanfaatan, pengawetan dan perlindungan sumber daya alam di dalam kawasan. Dalam upaya peningkatan pengelolaan kawasan TNTC, pihak Balai Besar Taman Nasional Teluk Cenderawasih baik secara pribadi maupun bersama dengan para mitra telah melaksanakan beberapa kegiatan yang berkaitan dengan pariwisata hiu paus serta pemberdayaan dan peningkatan kapasitas masyarakat (Purmadewi, 2018). Beberapa kegiatan penelitian terkait hiu paus pernah dilaksanakan sejak tahun 2010 termasuk pemasangan penanda radio frequency identification (RFID), pengambilan photoID hiu paus, pemantauan hiu paus, penyusunan database hiu paus (3-6 Oktober 2012 hingga saat ini), pemasangan tag satelit winmount dan penjelasannya, peninjauan kesehatan hiu paus dan monitoring kemunculan hiu paus. 
Dinamika Sosial Budaya, Vol 22, No. 2, Desember 2020, pp 148-157

p-ISSN: 1410-9859\& e-ISSN: 2580-8524

http://journals.usm.ac.id/index.php/idsb

Kegiatan-kegiatan ini tidak hanya hasil kerja dari BBTNTC semata, melainkan berkat kerjasama dengan berbagai pihak seperti World Wildlife Fund Indonesia (WWFIndonesia), Conservation International (CI), Universitas Negeri Papua (UNIPA (Prayitno, 2020).

\title{
KESIMPULAN
}

\begin{abstract}
Kemitraan konservasi merupakan sebuah terobosan yang sangat baik dalam menyelesaiakan persoalan tenurial di Indonesia. Khusus di Papua, terdapat beberapa persoalan yang harus dibenahi dalam mengimplementasikan konsep kemitraan konservasi. Salah satu pembanahan yang patut dilakukan adalah dengan menguatkan peran lembaga adat Papua. Hal ini penting untuk dilakukan karena lembaga adat memiliki peran sentral dalam membumikan konsep kemitraan konservasi. Selain itu beberapa model yang dapat dilakukandalam rangka program kemitraan konservasi adalah dengan menjadikan beberapa hutan di Papua sebagai kawasan wisata yang dikelola oleh masyarakat. Adanya kawasan wisata berbasis hutan, dapat menyelesaikan beberapa persoalan sekaligus yakni perekonomian masyarakat dan konservasi hutan. Oleh karena itu keterlibatan adat menjadi penting untuk diberikan ruang yang lebih besar. Sehingga diharapkan dalam praktiknya nanti, kemitraan konservasi dapat menjadi satu perangkat aturan pengelolaan hutan untuk menjaga hutan Papua.
\end{abstract}




\section{DAFTAR PUSTAKA}

Asriyati. (2019, August 22). Mengintip Kebiasaan Suku Korowai, Pemilik Rumah Pohon Tertinggi di Papua. Papua, 1indonesia.

Damarraya, A., Ratnasar, M., \& Rhama, D. F. (2019). DEFORESTASI. jakarta : Kementerian Lingkungan Hidup dan Kehutanan.

Earth, D. t. (2005, May). Targeting illegal logging in West Papua.

Elisabeth, A. (2019, February 6). Tak Ada Kejelasan Kelola Hutan Adat di Papua jadi Celah Pebisnis Kayu Ilegal. Jayapura, Indonesia.

KLHK. (2015). Model Pengelolaan Kawasan Konservas Berbasis Ekosistem. Jakarta: Litbang Kementerian Lingkungan Hidup dan Kehutanan.

KLHK. (2020, April 23). Hutan dan Deforestasi Indonesia Tahun 2019. Retrieved September 25, 2020, from PPID Kementerian Lingkungan Hidup dan Kehutanan: http://ppid.menlhk.go.id/siaran_pers/ browse/2435

Kusnandar, V. B. (2019, August 20). Inilah Deforestasi di Indonesia Periode 1990-2017. Retrieved September 25, 2020, from databoks: https://databoks.katadata.co.id/datap ublish/2019/08/20/inilah-deforestasidi-indonesia-periode-1990-2017

Muhajir, M. (2018). IUPHHK-MHA dan Masa Depan Pengelolaan Hutan oleh Masyarkat Adat Papua. Jakarta: Auriga.
Mutiono, S. (2020). MENGENAL KEMITRAAN KONSERVASI.

Retrieved september 25, 2020, from bbksda-papuabarat: https://bbksdapapuabarat.com/mengenalkemitraan-konservasi/

Nainggolan, S. Y. (2019, August 21). Lahan di Papua Terancam Deforestasi. Jakrta, Indonesia.

Prayitno, D. E. (2020). Kemitraan Konservasi Sebagai Upaya Penyelesaian Konflik Tenurial dalam Pengelolaan Kawasan. Jurnal Hukum Lingkungan Indonesia, 190.

Purmadewi, G. C. (2018, April 4). Pengelolaan Taman Nasional Teluk Cenderawasih. Jauapura, I, Idonesia.

Surono, A. (2008). Penyelesaian Konflik Sumber Daya Hutan Secara Kolaboratif Kemitraan. Jakarta : Universitas Al-Azhar Indonesia.

TeropongNews. (2020, July 4). Koalisi Masyarakat Sipil Tuntut Pelaku Pembalakan Liar di Usut Tuntas. Sorong, Papua, Indonesia . 